\title{
Hexavalent Chromium Removal by Citrus limonium Shell
}

\author{
Juan Manuel Vargas-Morales ${ }^{1}$, Diana Bautista-Mata ${ }^{1}$, Juan F. Cárdenas-González ${ }^{1}$, \\ Víctor Manuel Martínez-Juárez ${ }^{2}$, Ismael Acosta-Rodríguez ${ }^{1}$ \\ ${ }^{1}$ Laboratorio de Micología Experimental, Centro de Investigación y de Estudios de Posgrado, Facultad de Ciencias Químicas, \\ Universidad Autónoma de San Luis Potosí, San Luis Potosí, México \\ ${ }^{2}$ Área Académica de Medicina Veterinaria y Zootecnia, Instituto de Ciencias Agropecuarias, \\ Universidad Autónoma del Estado de Hidalgo, Tulancingo de Bravo, México \\ Email: iacosta@uaslp.mx
}

Received March 22, 2012; revised April 28, 2012; accepted May 24, 2012

\begin{abstract}
We studied the Chromium(VI) removal capacity in aqueous solution by the lemon shell, using the diphenylcarbazide method to evaluate the metal concentration. So, the highest biosorption of the metal $(50 \mathrm{mg} / \mathrm{L})$ occurs within $100 \mathrm{mi}-$ nutes, at $\mathrm{pH}$ of 1.0 , and $28^{\circ} \mathrm{C}$. According to temperature, the highest removal was observed at $60^{\circ} \mathrm{C}$, in 11 minutes, when the metal $(1 \mathrm{~g} / \mathrm{L})$ is completely adsorbed. At the analyzed concentrations of $\mathrm{Cr}(\mathrm{VI})$, lemon shell, showed excellent removal capacity, besides it removes efficiently the metal in situ (97.2\% removal, 7 days of incubation, $5 \mathrm{~g}$ of biomass). After 1 hour of incubation the studied biomass reduces $1.0 \mathrm{~g}$ of $\mathrm{Cr}(\mathrm{VI})$ with the simultaneous production of $\mathrm{Cr}(\mathrm{III})$; so it can be used to eliminate it from industrial wastewater.
\end{abstract}

Keywords: Chromium(VI); Biosorption; Remotion; Biomass; Chromium(III)

\section{Introduction}

Chromium(Cr) toxicity is one of the major causes of environmental pollution emanating from tannery effluents. This metal is used in the tanning of hides and leather, the manufacture of stainless steel, electroplating, textile dyeing and as a biocide in the cooling waters of nuclear power plants, resulting chromium discharges causing environmental concerns [1]. $\mathrm{Cr}$ exists in nine valence states ranging from -2 to +6 . From these, only the hexavalent $[\mathrm{Cr}(\mathrm{VI})]$ and trivalent chromium [Cr(III)] have primary environmental significance due they are the most stable oxidated forms in the environment [2]. Both are found in various bodies of water and wastewaters [3]. $\mathrm{Cr}(\mathrm{VI})$ typically exists in one of these two forms: chromate $\left(\mathrm{CrO}_{4}^{-2}\right)$ or dichromate $\left(\mathrm{Cr}_{2} \mathrm{O}_{7}^{-2}\right)$, depending on the $\mathrm{pH}$ of the solution [3]. These two divalent oxyanions are very water soluble and poorly adsorbed by soil and organic matter, making them mobile in soil and groundwater [2]. Both chromate anions represent acute and chronic risks to animals and human health, since they are extremely toxic, mutagenic, carcinogenic and teratogenic [4]. In contrast to $\mathrm{Cr}(\mathrm{VI})$ forms, the $\mathrm{Cr}(\mathrm{III})$ species: predominantly hydroxides, oxides or sulphates, are less water soluble, mobile (100 times less toxic) [5] and (1000 times less) mutagenic [6]. The principal techniques for recovering or removing $\mathrm{Cr}(\mathrm{VI})$, from wastewater are: chemical reduction and precipitation, adsorption on acti- vated carbon, ion exchange and reverse osmosis in a basic medium [7]. However, these methods have certain drawbacks, namely high cost, low efficiency, generation of toxic sludge or other wastes that require disposal and imply operational complexity [8].

In this context, considerable attention has been focused in recent years upon the field of biosorption for the removal of heavy metal ions from aqueous effluents [9]. The process of heavy metal removal by biological materials is known as biosorption. Biomass viability does not affect the metal uptake. Therefore any active metabolic uptake process is currently considered to be a negligible part of biosorption. Various biosorbents have been tried, which include seaweeds, moulds, yeast, bacteria, crab shells, agricultural products such modified corn stalks, [10], hazelnut shell [11], orange shell [12] tamarind shell [13]. It has also been reported that some of these biomass can reduce Chromium(VI) to Chromium(III), like tea fungal biomass [14]; Mesquite [15], Eucalyptus bark [16], red roses waste biomass [17], and Yohimbe bark [18]. The present study is undertaken with following objective: Investigate the use of Citrus limonium shell for the biosorption of Chromium(VI) in aqueous solution.

\section{Experimental}

\subsection{Biosorbent Used: Citrus limonium Shell}

The shell was obtained from the fruits harvested and of- 
fered in the marketplace Republic, between the months of June 2010 to September 2010, of the capital city of San Luis Potosi, SLP. Mexico. To obtain the biomass, lemon rind washed with water trideionized 72 hours under constant stirring, with water changes every 12 hours. Subsequently, boiled 1 hour to remove traces of the fruit was dried at $80^{\circ} \mathrm{C}$ for 12 hours in the oven, ground in blender and stored in amber vials until use.

\subsection{Determination of Hexavalent, Trivalent, and Total Cr}

Hexavalent chromium and trivalent chromium were quantified by a spectrophotometric method employing diphenylcarbazide and Chromazurol S, respectively [19,20], total $\mathrm{Cr}$ was determined by electrothermal atomic absorption spectroscopy [19].

The values shown in the results section are the mean from three experiments carried out by triplicate.

\section{Results and Discussion}

\subsection{Effect of Incubation Time and $\mathbf{p H}$}

Figure 1 shows the effect of the incubation time and $\mathrm{pH}$. The optimum time and $\mathrm{pH}$ for $\mathrm{Cr}(\mathrm{VI})$ removal was 100 min and $\mathrm{pH}$ 1.0, at constant values of biosorbent dosage $(1 \mathrm{~g} / 100 \mathrm{~mL})$, initial metal concentration $(50 \mathrm{mg} / \mathrm{L})$, and temperature $\left(30^{\circ} \mathrm{C}\right)$. The literature [12], report a optimum time of $60 \mathrm{~min}$, for the remotion of lead by orange Shell, 30 min and 2 hours for the remotion of $\operatorname{Cr}(\mathrm{VI})$ by the tamarind shell and eucalyptus bark $[13,16]$. Changes in the permeability of unknown origin, could partly explain the differences found in the incubation time, providing greater or lesser exposure of the functional groups of the cell wall of biomass analyzed. Adsorption efficiency of $\mathrm{Cr}(\mathrm{VI})$ was observed maximum at $\mathrm{pH} 1.0$ with Citrus limonium waste biomass. This was due to the dominant species $\left(\mathrm{CrO}_{4}^{-2}\right.$ and $\left.\mathrm{Cr}_{2} \mathrm{O}_{7}^{-2}\right)$ of $\mathrm{Cr}$ ions in solution expected to interact more strongly with the ligands carrying positive charges [21]. These results are like for tamarind shell [13], but the most of authors report an optimum $\mathrm{pH}$ of 2.0 like Tamarind shell [22], eucalyptus bark [16], bagassa and sugarcane pulp, coconut fibers and wool, [23], for the tamarind shell treated with oxalic acid [24], at $\mathrm{pH}$ of 2.0 and 5.0 for the mandarin bagassa [25], and almond green hull [26].

\subsection{Effect of Temperature}

Temperature is found to be a critical parameter in the bioadsorption of $\mathrm{Cr}(\mathrm{VI})$ (Figure 2). The highest removal was observed at $60^{\circ} \mathrm{C}$. At this point the total removal of the metal is carried out. The results are coincident for tamarind Shell with $95 \%$ of remotion at $58^{\circ} \mathrm{C}$ and 3 hours [22], for the adsorption of Cadmium(II) from aqueous solution on natural and oxidized corncob $\left(40^{\circ} \mathrm{C}\right.$ and 5 days) [27], but this are different for the mandarin waste [25], Caladium bicolor (wild cocoyam) biomass [28], and Saccharomyces cerevisiae [29]. The increase in temperature increases the rate of removal of Chromium(VI) and decreases the contact time required for complete removal of the metal, to increase the redox reaction rate [22].

\subsection{Effect of Initial Metal Concentration}

On the other hand, at low metal concentrations (100, 400, 500 and $1000 \mathrm{mg} / \mathrm{L}$ ), biomass studied, shows the best results for removal, adsorbing $100 \%$ at 18 minutes, while 200 and 300 of metal is removed $100 \%$ of $\mathrm{Cr}(\mathrm{VI})$ up to 35 minutes of incubation (Figure 3(a)), while at $28^{\circ} \mathrm{C}$ the same concentrations are removed at $3.5 \mathrm{~h}$ (Figure 3(b)). Also, we observed the development of a blue-green and a white precipitate, which changes more rapidly at higher temperatures (date not shown). The results are coincident for tamarind Shell $[13,22]$. With respect to other biomass used, most authors report lower removal efficiencies of metal, for example: $45 \mathrm{mg} / \mathrm{L}$ for eucalyptus bark [16], 13.4 and $17.2 \mathrm{mg} / \mathrm{L}$ for bagassa and sugar cane pulp, 29 $\mathrm{mg} / \mathrm{L}$ coconut fibers, $8.66 \mathrm{mg} / \mathrm{L}$ for wool [23], 25 and 250 $\mathrm{mg} / \mathrm{L}$ of chitin and chitosan [30], and $1 \mathrm{mg} / \mathrm{L}$ for cellulose

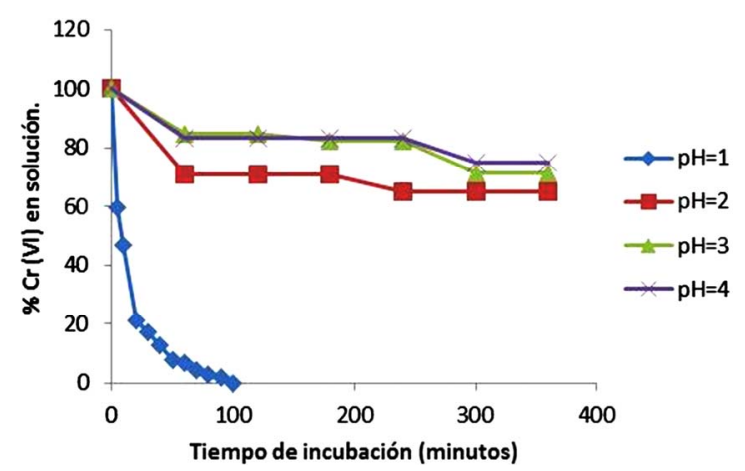

Figure 1. Effect of incubation time and pH on Chromium(VI) remotion by Citrus limonium (Shell: $50 \mathrm{mg} / \mathrm{L} \mathrm{Cr}(\mathrm{VI}), 100$ rpm, $28^{\circ} \mathrm{C}$ ).

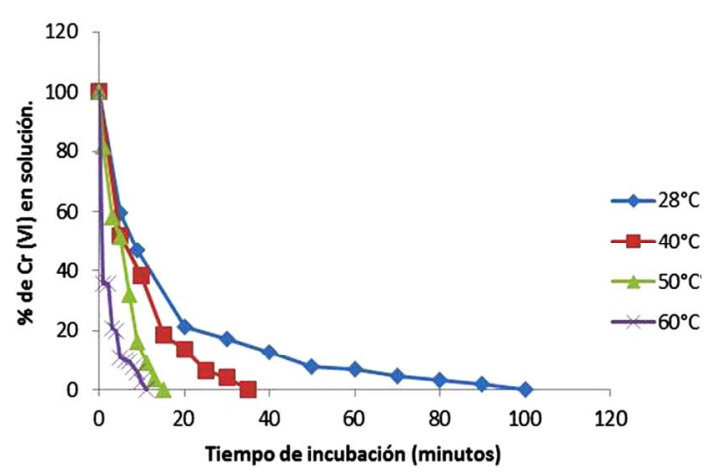

Figure 2. Effect of temperature on Chromium(VI) remotion by Citrus limonium (Shell: $50 \mathrm{mg} / \mathrm{L} \mathrm{Cr}(\mathrm{VI}), \mathrm{pH} 1.0,100$ rpm). 


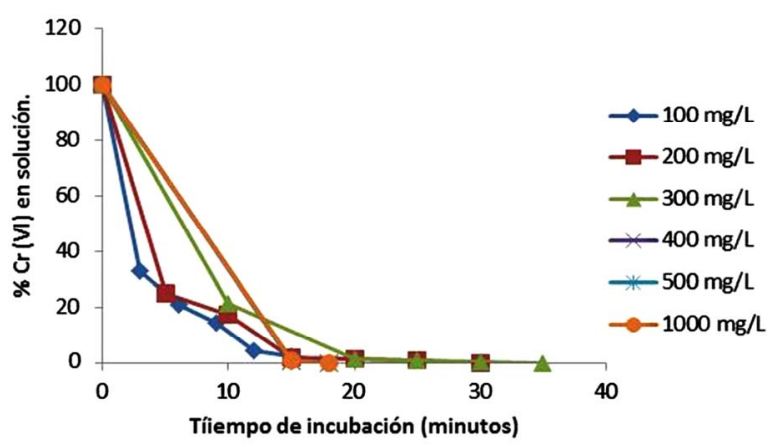

(a)

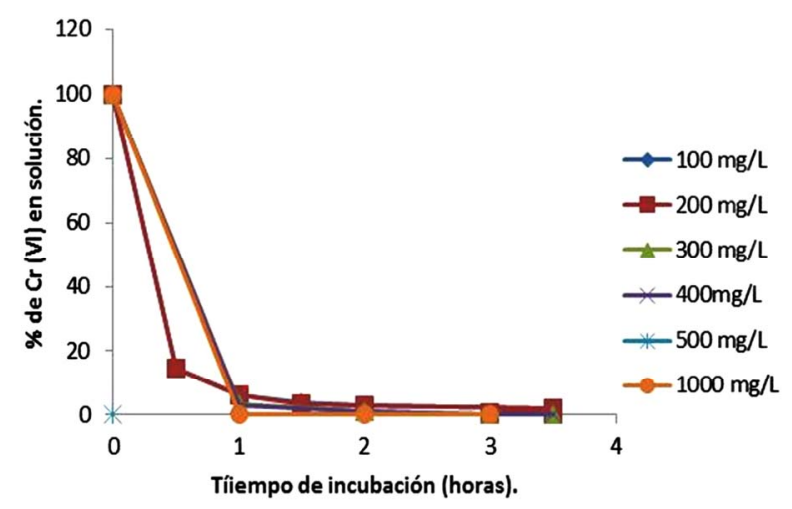

(b)

Figure 3. Effect of initial metal concentration on Chromium(VI) remotion by Citrus limonium (pH 1.0, 100 rpm). (a) $-60^{\circ} \mathrm{C}$; (b) $-28^{\circ} \mathrm{C}$.

acetate [31]. The increase in initial concentration of $\mathrm{Cr}(\mathrm{VI})$, results in the increased uptake capacity and decreased \% removal of $\operatorname{Cr}(\mathrm{VI})$. This was due to the increase in the number of ions competing for the available functions groups on the surface of biomass [22].

\subsection{Effect of Biosorbent Dose}

The influence of biomass on the removal capacity of $\mathrm{Cr}$ (VI) was depicted in Figure 4. If we increase the amount of biomass also increases the removal of $\mathrm{Cr}(\mathrm{VI})$ in solution (100\% of remotion, with $5 \mathrm{~g}$ of biomass, 40 minutes), with more biosorption sites of the same, because the amount of added biosorbent determines the number of binding sites available for metal biosorption [33]. Similar results have been reported for modified corn stalks [10], tamarind shell [13], and Mucor hiemalis and Rhizopus nigricans, although latter with $10 \mathrm{~g}$ of biomass [1,34], but are different from those reported for biomass wastes from the mandarin (gabassa), whit an optimal concentration of biomass of $100 \mathrm{mg} / \mathrm{L}$ [25].

\subsection{Time Course of Cr(VI) Decrease and Cr(III) Production}

The ability of the Citrus limonium shell to lower the initial $\mathrm{Cr}(\mathrm{VI})$ of $1.0 \mathrm{~g} / \mathrm{L}$, and $\mathrm{Cr}(\mathrm{III})$ production in solution was analyzed. Figure 5 shows that the shell exhibited a remarkable efficiency to diminish $\mathrm{Cr}(\mathrm{VI})$ level with the concomitant production of $\mathrm{Cr}$ (III) in the solution (indicated by the formation of a blue-green color and a white precipitate, and his determination for Cromazurol S, date not shown) [20]. Thus, after 1 hour of incubation, the shell biomass caused a drop in Cr(VI) from its initial concentration of $1.0 \mathrm{~g} / \mathrm{L}$ to almost undetectable levels, and the decrease level occurred without change significant in total Cr content. As expected, total Cr concentration remained constant over time, in solution control. These observations indicate that Citrus limonium shell is able to reduce $\mathrm{Cr}(\mathrm{VI})$ to $\mathrm{Cr}(\mathrm{III})$ in solution. Furthermore, as the Citrus limonium shell contains vitamin $\mathrm{C}$ and some carbohydrates, we found that vitamin $\mathrm{C}$ and cystine quickly reduce $\mathrm{Cr}(\mathrm{VI})$ to $\mathrm{Cr}(\mathrm{III})$, and could be very important part in the metal reduction, confirming some reports in the literature $[2,3,37,39,40]$. There are two mechanisms by which chromate could be reduced to a lower toxic oxidation state by an enzymatic reaction. Currently, we do not know whether the shell biomass used in this study express and $\mathrm{Cr}(\mathrm{VI})$ reducing enzyme(s).

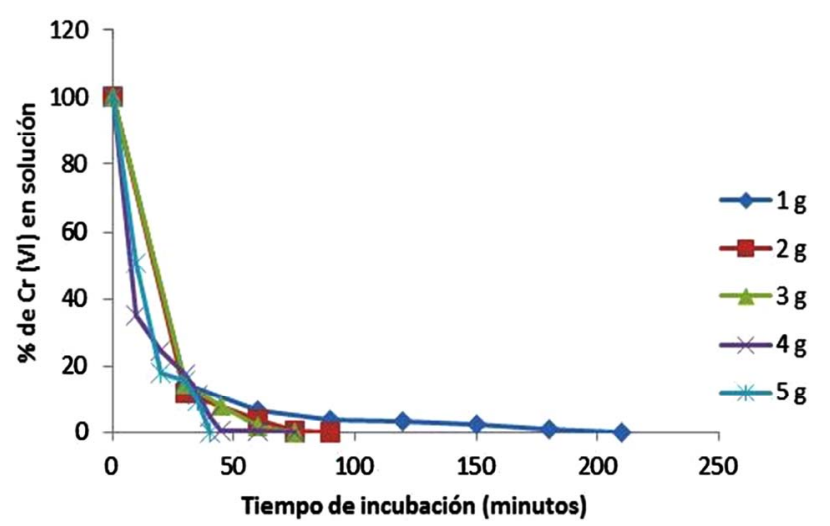

Figure 4. Effect of biomass concentration on the removal of $200 \mathrm{mg} / \mathrm{L} \mathrm{Cr}(\mathrm{VI})\left(60^{\circ} \mathrm{C}, \mathrm{pH}=1.0,100 \mathrm{rpm}\right)$.

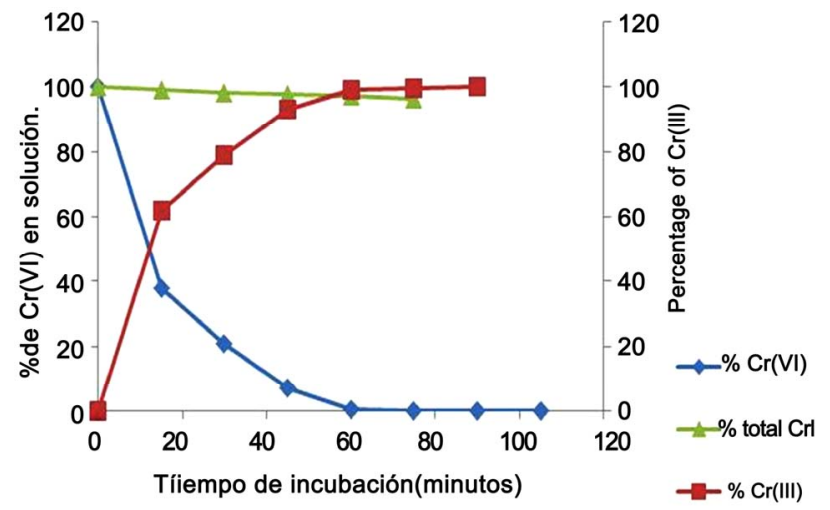

Figure 5. Time-course of $\mathrm{Cr}$ (VI) decrease and $\mathrm{Cr}$ (III) production in solution with $1.0 \mathrm{mg} / \mathrm{L} \mathrm{Cr}(\mathrm{VI})\left(100 \mathrm{rpm}, 28^{\circ} \mathrm{C}\right.$, pH 4.0). 
Further studies are necessary to extend our understanding of the effects of coexisting ions on the $\mathrm{Cr}(\mathrm{VI})$ reducing activity of the biomass reported in this study. $\mathrm{Cr}(\mathrm{VI})$ reducing capability has been described in some reports in the literature $[2-4,8,13,15,18,35-38]$. Biosorption is the second mechanism by which the chromate concentration could be reduced, because the biomass shell can be regarded as a mosaic of different groups that could form coordination complexes with metals, and our observations are like to the most of the reports in the $[3,4,8$, 13,15,18,35-38].

\subsection{Removal of $\operatorname{Cr}(\mathrm{VI})$ in Industrial Wastes with Citrus limonium Shell}

We adapted a water-phase bioremediation assay to explore possible usefulness of Citrus limonium shell, for eliminating $\mathrm{Cr}(\mathrm{VI})$ from industrial wastes, the biomass was incubated with non sterilized contaminated soil containing $297 \mathrm{mg} \mathrm{Cr}(\mathrm{VI}) / \mathrm{g}$, suspended in trideionized water. It was observed that after seven days of incubation with the biomass, the $\mathrm{Cr}(\mathrm{VI})$ concentration of soil sample decrease 97.2\% (Figure 6), and the decrease level occurred without change significant in total $\mathrm{Cr}$ content, during the experiments. In the experiment carried out in the absence of the biomass, the $\mathrm{Cr}(\mathrm{VI})$ concentration of the soil samples decreased by about of $18 \%$ (date not shown); this might be caused by indigenous microflora and (or) reducing components present in the soil. The chromium removal abilities of Citrus limonium shell are equal or better than those of other reported biomass, for example tamarind shell [13], Mammea americana [37], Candida maltose RR1 [35]. In particular, this biomass was superior to the other biomass because it has the capacity for efficient chromium reduction under acidic conditions. Many of the $\mathrm{Cr}(\mathrm{VI})$ reduction studies were carried out at neutral $\mathrm{pH}$ [41]. Aspergillus niger also has the ability to reduce and adsorb $\mathrm{Cr}(\mathrm{VI})$ [41]. When the initial concentration of $\mathrm{Cr}(\mathrm{VI})$ was $500 \mathrm{ppm}$, A. niger mycelium removed $8.9 \mathrm{mg}$ of chromium/g dry weight of mycelium in 7 days.

\subsection{Desorption of Cr(VI) by Different Solutions}

Furthermore, we examined the ability of different solutions to desorb the metal biosorbed $(250 \mathrm{mg} / \mathrm{L})$ for the Citrus limonium biomass, obtaining high efficiency with $0.1 \mathrm{~N} \mathrm{NaOH}$ and $0.5 \mathrm{~N}$ (83\% and $62.86 \%$ respectively) (Figure 7), which are less than reported for desorption of Chromium(VI) with alkaline solutions $(100 \%, \mathrm{pH}=9.5)$, $1.0 \mathrm{~N} \mathrm{NaOH}(95 \%)$ and a hot solution of $\mathrm{NaOH} / \mathrm{Na}_{2} \mathrm{CO}_{3}$ (90\%), respectively [42,43], and are higher than that reported (14.2\%) using 0.2 M NaOH [44]. This indicates that binding of metal to biomass is not as strong and that it can be used up to 6-desorption cycles of removal, which

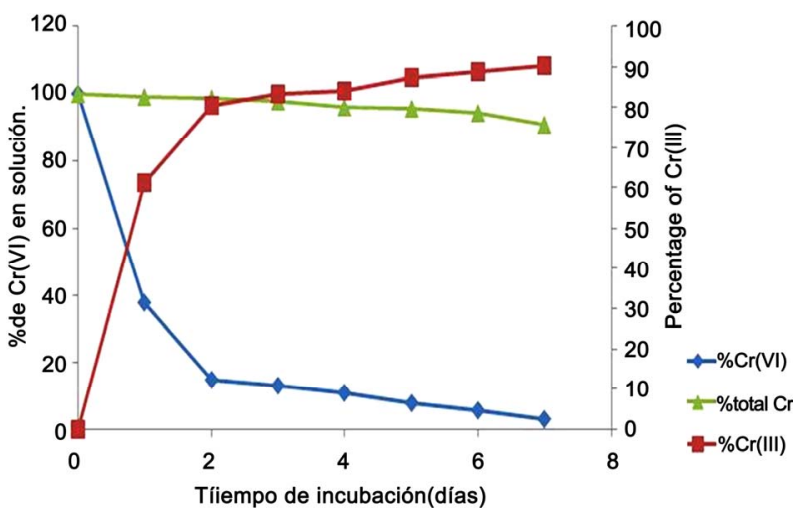

Figure 6. Removal of Chromium(VI) in industrial wastes incubated with the biomass $\left(100 \mathrm{rpm}, 28^{\circ} \mathrm{C}\right.$, of contaminated soil, $297 \mathrm{mg} \mathrm{Cr}(\mathrm{VI}) / \mathrm{g}$ soil).

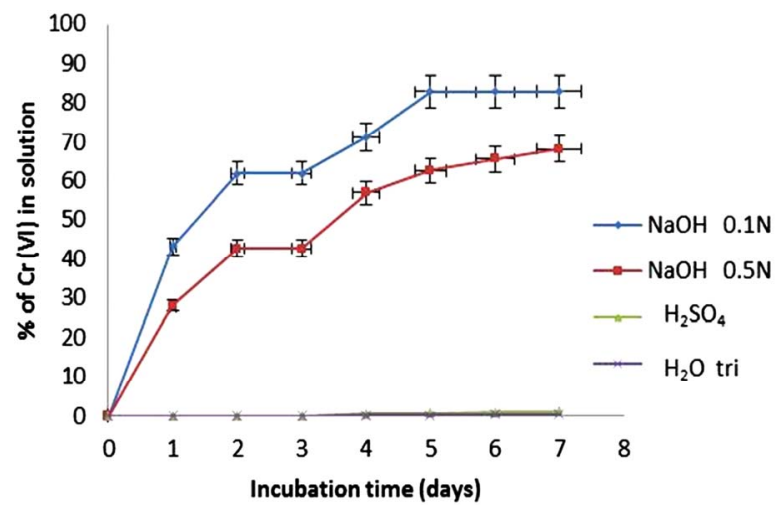

Figure 7. Desorption of Chromiun(VI) $(250 \mathrm{mg} / \mathrm{L})$ by different solutions ( $1 \mathrm{~g}$ of biomass. $\left.28^{\circ} \mathrm{C}, 100 \mathrm{rpm}\right)$.

further lowers the metal removal process of niches contaminated with it.

\section{Conclusion}

The Citrus limonium biomass complete capacity showed of biosorption and reduction concentrations of $1.0 \mathrm{~g} / \mathrm{L}$ $\mathrm{Cr}(\mathrm{VI})$ in solution after 7 days of incubation, at $28^{\circ} \mathrm{C}$, $100 \mathrm{rpm}$ with $1 \mathrm{~g}$ of biomass. These results suggest the potential applicability of Citrus limonium biomass for the remediation of $\mathrm{Cr}(\mathrm{VI})$ from polluted soils in the fields.

\section{REFERENCES}

[1] R. S. Bai and T. E. Abraham, "Biosorption of Chromium (VI) from Aqueous Solution by Rhizopus nigricans," Bioresource Technology, Vol. 79, No. 1, 2001, pp. 73-81. doi:10.1016/S0960-8524(00)00107-3

[2] W. A. Smith, W. A. Apel, J. N. Petersen and B. M. Peyton, "Effect of Carbon and Energy Source on Bacterial Chromate Reduction," Bioremediation Journal, Vol. 6, No. 3, 2002, pp. 205-215. doi:10.1080/10889860290777567

[3] H. Seng and Y. T. Wang, "Biological Reduction of Chro- 
mium by E. coli,” Journal of Environmental Engineering, Vol. 120, No. 3, 1994, pp. 560-572. doi:10.1061/(ASCE)0733-9372(1994)120:3(560)

[4] T. L. Marsh and M. J. McInerney, "Relationship of Hydrogen Bioavailability to Chromate Reduction in Aquifer Sediments," Applied and Environmental Microbiology, Vol. 67, No. 4, 2001, pp. 1517-1521. doi:10.1128/AEM.67.4.1517-1521.2001

[5] S. Beszedits, "Chromium Removal from Industrial Wastewaters,” In: J. O. Nriagu and E. Nieboer, Eds., Chromium in the Natural and Human Environments, John Wiley, New York, 1988, pp. 232-263.

[6] G. Lofroth and B. N. Ames, "Mutagenicity of Inorganic Compounds in Salmonella typhimurium: Arsenic, Chromium and Selenium," Mutation Research, Vol. 53, No. 1, 1978, pp. 65-66.

[7] D. Park, Y. S. Yun, H. Y. Cho and J. M. Park, "Chromium Biosorption by Thermally Treated Biomass of the Brown Seaweed, Ecklonia sp.," Industrial and Engineering Chemistry Research, Vol. 43, No. 26, 2004, pp. 82268232. doi:10.1021/ie049323k

[8] Y. Sahin and A. Öztürk, "Biosorption of Chromium (VI) Ions from Aqueous Solution by the Bacterium Bacillus thuriengensis," Process Biochemistry, Vol. 40, No. 5, 2005, pp. 1895-1901. doi:10.1016/j.procbio.2004.07.002

[9] B. Volesky and Z. R. Holan, "Biosorption of Heavy Metals,” Biotechnology Progress, Vol. 11, No. 3, 1995, pp. 235-250. doi:10.1021/bp00033a001

[10] S. Chen, Q. Yue, B. Gao, Q. Li and X. Xu, "Removal of $\mathrm{Cr}(\mathrm{VI})$ from Aqueous Solution Using Modified Corn Stalks: Characteristic, Equilibrium, Kinetic and Thermodynamic Study," Chemical Engineering Journal, Vol. 168, No. 2, 2011, pp. 909-917. doi:10.1016/j.cej.2011.01.063

[11] G. Cimino, A. Passerini and G. Toscano, "Removal of Toxic Cations and Cr(VI) from Aqueous Solution by Halzelnut shell," Water Research, Vol. 34, No. 11, 2000, pp. 2955-2962. doi:10.1016/S0043-1354(00)00048-8

[12] A. B. Pérez-Marín, et al., "Removal of Cadmium from Aqueous Solutions by Adsorption onto Orange Waste," Journal of Hazardous Materials, Vol. 139, No. 1, 2007, pp. 122-131. doi:10.1016/j.jhazmat.2006.06.008

[13] I. Acosta, V. López, E. Coronado, J. F. Cárdenasa and V. M. Martínez, "Remoción de Cromo(VI) Por la Biomasa de la Cáscara de Tamarindo, (Tamarindus indica)," Revista de Biotecnología y Bioingeniería, Vol. 14, No. 3, 2010, pp. 11-23.

[14] N. R. N. Razmovski and M. B. Sciban, "Effect of Different Conditions on $\mathrm{Cu}(\mathrm{II})$ and $\mathrm{Cr}(\mathrm{VI})$ Biosorption by Dried Waste Tea Fungal Biomass,” Acta Periodica Technologica, Vol. 38, 2007, pp. 1-19.

[15] M. V. Aldrich, J. L. GardeaTorresdey, J. R. Peralta Videa and J. G. Parsons, "Uptake and Reduction of Cr(VI) to Cr(III) by Mesquite (Prosopis ssp.): Chromate-Plant Interaction in Hydroponics and Solid Media Studied Using XAS,” Environmental Science Technology, Vol. 37, No. 9, 2003, pp. 1859-1864. doi:10.1021/es0208916

[16] V. Sarin and K. K. Pant, "Removal of Chromium from
Industrial Waste by Using Eucalyptus Bark,” Bioresource Technology, Vol. 97, No. 1, 2006, pp. 15-20.

doi:10.1016/j.biortech.2005.02.010

[17] F. Shafqat, H. N. Bhatti, M. A. Hanif and A. Zubair, "Kinetic and Equilibrium Studies of $\mathrm{Cr}(\mathrm{III})$ and $\mathrm{Cr}(\mathrm{VI})$ Sorption from Aqueous Solution Using Rosagruss an Teplitz (Red rose) Waste Biomass,” Journal Chile Chemistry Society, Vol. 53, No. 4, 2008, pp. 1667-1672.

[18] N. Fiol, C. Escudero and I. Villaescusa, "Chromium Sorption and $\mathrm{Cr}(\mathrm{VI})$ Reduction to $\mathrm{Cr}(\mathrm{III})$ by Grape Stalks and Yohimbe Bark,” Bioresource Technology, Vol. 99, No. 11, 2008, pp. 5030-5036. doi:10.1016/j.biortech.2007.09.007

[19] A. E. Greenberg, L. S. Clesceri and A. D. Eaton, "Standard Methods for the Examination of Water and Wastewater," 18th Edition, American Public Health Association, Washington, DC, 1992.

[20] R. P. Pantaler and I. V. Pulyaeva, “A Spectrophotometric Study of Complexation between Chromium and Chromazurol S," Analytical Chemistry (Moscow), Vol. 40, 1985, pp. 1634-1639.

[21] V. K. Gupta, A. K. Shrivastava and N. Jain, "Biosorption of Chromium(VI) from Aqueous Solution by Green Algae Spirogyra Species” Water Research, Vol. 35, No. 17, 2001, pp. 4079-4085. doi:10.1016/S0043-1354(01)00138-5

[22] G. S. Agarwal, H. Kumar and S. Chaudari, "Biosorption of Aqueous Chromium(VI) by Tamarindus indica seeds," Bioresource Technology, Vol. 97, No. 7, 2006, pp. 949956. doi:10.1016/j.biortech.2005.04.030

[23] M. Dakiki, M. Khamis, A. Manassra and M. Mereb, "Selective Adsorption of Chromium(VI) in Industrial Wastewater Using Low Cost Abundantly Adsorbents," Advances Environmental Research, Vol. 6, No. 4, 2002, pp. 533-540. doi:10.1016/S1093-0191(01)00079-X

[24] R. S. Popuri, A. Jammala, K. Naga Suresh and K. Abuburi, "Biosorption of Hexavalent Chromium Using Tamarind (Tamarindus indica) Fruit Shell-A Comparative Study,” Journal of Biotechnology, Vol. 10, No. 3, 2007, pp. 358-367.

[25] A. Zubair, H. N. Bhatti, M. A. Hanif and F. Shafqat, "Kinetic and Equilibrium Modeling for $\mathrm{Cr}(\mathrm{III})$ and $\mathrm{Cr}(\mathrm{VI})$ Removal from Aqueous Solutions by Citrus reticulatawaste Biomass," Water Air Soil Pollution, Vol. 191, No. 1-4, 2008, pp. 305-318. doi:10.1007/s11270-008-9626-y

[26] M. Sharanavard, A. Ahmadpourand and M. Reza Doosti, "Biosorption of Hexavalent Chromium Ions from Aqueous Solutions using Almond Green Hull as a Low-Cost Biosorbent," European Journal of Scientific Research, Vol. 58, No. 3, 2011, pp. 392-400.

[27] R. Leyva-Ramos, L. A. Bernal-Jacome and I. AcostaRodriguez, "Adsorption of Cadmium(II) from Aqueous Solution on Natural and Oxidized Corncob," Separation and Purification Technology, Vol. 45, No. 1, 2005, pp. 41-49. doi:10.1016/j.seppur.2005.02.005

[28] M. H. Jnr and A. I. Spiff, "Effects of Temperature on the Sorption of $\mathrm{Pb}^{2+}$ and $\mathrm{Cd}^{2+}$ from Aqueous Solution by $\mathrm{Ca}$ ladium bicolor (Wild Cocoyam) Biomass," Electronic Journal of Biotechnology, Vol. 8, No. 2, 2005, pp. 162- 
169. doi:10.2225/vol8-issue2-fulltext-4

[29] A. Ozer and D. Ozer, "Comparitive Study of the Biosorption of $\mathrm{Pb}(\mathrm{II}), \mathrm{Ni}(\mathrm{II})$ and $\mathrm{Cr}(\mathrm{VI})$ Ions onto S. cerevisiae: Determination of Biosorption Heats," Journal of $\mathrm{Ha}$ zardous Materials, Vol. 100, No. 1-3, 2003, pp. 219-229. doi:10.1016/S0304-3894(03)00109-2

[30] Y. Sag and Y. Aktay, "Kinetic Studies on Sorption of $\mathrm{Cr}(\mathrm{VI})$ and CU(II) Ions by Chitin, Chitosan and Rhizopus arrhizus,” Biochemical Engineering Journal, Vol. 12, No. 2, 2002, pp. 143-153. doi:10.1016/S1369-703X(02)00068-2

[31] G. Arthanareeswaran, P. Thanikaivelan, N. Jaya, D. Mohan and M. Raajenthiren, "Removal of Chromium From Aqueous Solution Using Cellulose Acetate and Sulfonated Poly (Ether Ketone) Blend Ultrafiltration Membranes,” Biochemical Engineering Journal, Vol. 12, 2002, pp. 43-153.

[32] M. A. Hanif, R. Nadeem, H. N. Bhatti, N. R. Ahmad and T. M. Ansari, "Ni(II) Biosorption by Cassia fistula (Golden Shower) Biomass,” Journal of Hazardous Materials, Vol. 139, No. 2, 2007, pp. 345-355. doi:10.1016/j.jhazmat.2006.06.040

[33] C. Cervantes, J. Campos-García, S. Devars, F. GutiérrezCorona, H. Loza-Tavera, J. C. Torres-Gúzman and R. Moreno-Sánchez, "Interactions of Chromium with Microorganisms and Plants," FEMS Microbiology Review, Vol. 25, No. 3, 2001, pp. 335-347. doi:10.1111/j.1574-6976.2001.tb00581.x

[34] N. Tewari, P. Vasudevan and B. Guha, "Study on Biosorption of Cr(VI) by Mucor hiemalis,” Biochemical Engineering Journal, Vol. 23, No. 2, 2005, pp. 185-192. doi:10.1016/j.bej.2005.01.011

[35] R. Ramírez-Ramírez, C. Calvo-Méndez, M. Avila-Rodríguez, P. Lappe, M. Ulloa, R. Vázquez-Juárez and J. F. Gutiérrez-Corona, "Cr(VI) Reduction in a Chromate-ReSistant Strain of Candida maltose Isolated from the Leather Industry,” Antonie van Leeuwenhoek, Vol. 85, No. 1, 2004, pp. 63-68. doi:10.1023/B:ANTO.0000020151.22858.7f

[36] D. Park, Y. S. Yung and J. M. Park, "Reduction of Hexavalent Chromium with the Brown Seaweed Ecklonia
Biomass,” Environmental Science \& Technology, Vol. 38, No. 18, 2004, pp. 4860-4864. doi:10.1021/es035329+

[37] I. Acosta, P. Sandoval, D. Bautista, N. Hernández, J. F. Cárdenas and V. M. Martínez, "Bioadsorción de Cromo(VI) Por la Cáscara de Mamey (Mammea americana L.)," Avances en Ciencias e Ingeniería, Vol. 3, No. 2, in Press 2012.

[38] J. F. Cárdenas-González and I. Acosta-Rodríguez "Hexavalent Chromium Removal by a Paecilomyces sp. Fungal," In: S. S. Shaukat, Ed., Progress in Biomass and Bioenergy Production, 2011, pp. 133-150.

[39] X. R. Xu, H. B. Li, J. D. Gu and X. Y. Li, "Kinetics of the Reduction of Chromium(VI) by Vitamin C," Environmental Toxicology and Chemistry, Vol. 24, No. 6, 2005, pp. 1310-1314. doi:10.1897/04-238R.1

[40] Y. Liu, et al., "Remediation of Cr(VI) in Solution Using Vitamin C," Journal of Zhejiang University Science, Vol. 6, No. 6, 2005, pp. 540-542. doi:10.1631/jzus.2005.B0540

[41] T. Fukuda, Y. Ishino, A. Ogawa, K. Tsutsumi and H. Morita, "Cr(VI) Reduction from Contaminated Soils by Aspergillus sp. N2 and Penicillium sp. N3 Isolated from Chromium Deposits,” Journal of General and Applied Microbiology, Vol. 54, No. 5, 2008, pp. 295-303. doi:10.2323/jgam.54.295

[42] K. K. Singh, S. H. Hasan, M. Talat, V. K. Singh and S. K. Gangwar, "Removal of Cr(VI) from Aqueous Solutions Using Wheat Bran,” Chemical Engineering Journal, Vol. 151, No. 1-3, 2009, pp. 113-121. doi:10.1016/j.cej.2009.02.003

[43] S. Gupta and B. V. Babu, "Removal of Toxic Metal $\mathrm{Cr}(\mathrm{VI})$ from Aqueous Solutions Using Sawdust as Adsorbent: Equilibrium, Kinetics and Regeneration Studies," Chemical Engineering Journal, Vol. 150, No. 2-3, 2009, pp. 352-365. doi:10.1016/j.cej.2009.01.013

[44] X. S. Wang, Y. P. Tang and S. R. Tao, "Kinetics, Equilibrium and Thermodynamic Study on Removal of Cr(VI) from Aqueous Solutions Using Low-Cost Adsorbent Alligator Weed,” Chemical Engineering Journal, Vol. 148, No. 2-3, 2009, pp. 217-225. doi:10.1016/j.cej.2008.08.020 